\title{
Sustainability assessment of the economic development of machine-building enterprises in a competitive environment
}

\section{Оценка устойчивости экономического развития машиностроительных предприятий в конкурентной среде}

\author{
Received: March 2, $2021 \quad$ Accepted: April 29, 2021
}

\author{
Written by: \\ Natalya V. Arsenieva ${ }^{67}$ \\ https://orcid.org/0000-0003-4265-6254 \\ https://www.scopus.com/authid/detail.uri?authorId=57219950801 \\ Lyudmila M. Putyatina ${ }^{68}$ \\ https://orcid.org/0000-0002-3050-1477 \\ https://www.scopus.com/authid/detail.uri?authorId=57219945805
}

\begin{abstract}
The article discusses the issues of sustainability assessment of the economic development of machine-building enterprises in the development of industry competition and many influential environmental factors. There is the need for an integrated approach to the problem of sustainability on the basis of development analysis: resource base of production; performance results; efficient use of economic potential, and balanced economic growth. The levels of sustainability of the economic development of enterprises and their features are considered. To determine the level of sustainability of the economic development of enterprises, methods of expert point estimates are used, which have sufficient ease of function and adequacy of the findings. For each area of the study, system of indicators, limits of change of each indicator involved in the calculations, and principles of aggregating them into a comprehensive assessment are substantiated. The development of the enterprise cannot be assessed in one of the directions, since this imbalances the work of the enterprise. Many factors are analyzed that allow each manufacturer to determine key areas and develop plans that contribute to increasing the level of business activity and sustainable development in the industry environment.
\end{abstract}

Keywords: approach based on efficiency; balanced development; resource approach; result approach; sustainability of the economic development.

\begin{abstract}
Аннотация
В статье рассматриваются вопросы оценки устойчивости экономического развития машиностроительных предприятий в условиях развития отраслевой конкуренции и множества влияющих факторов внешней среды. Акцентируется внимание на необходимости комплексного подхода к проблеме устойчивости на основе анализа развития: ресурсной базы производства; результатов деятельности; эффективности использования экономического потенциала, а также сбалансированности экономического роста. Рассматриваются уровни устойчивости экономического развития предприятий и их особенности. Для определения уровня устойчивости экономического развития предприятий используются методы экспертных бальных оценок, обладающие достаточной простотой использования и адекватностью получаемых выводов. Для каждого направления исследования обосновывается система показателей, пределы изменения каждого показателя, участвующего в расчетах, а также принципы агрегирования их в комплексную оценку. Развитие предприятия невозможно оценить по одному из направлений, поскольку при этом нарушается сбалансированность работы предприятия. Анализируется множество факторов, позволяющих каждому производителю определять ключевые направления и разработки планов, способствующих повышению уровня деловой активности и устойчивости развития в отраслевой среде.
\end{abstract}

Ключевые слова: устойчивость экономического развития, ресурсный подход, результатный подход, подход на основе эффективности, сбалансированность развития.

\footnotetext{
${ }^{67} \mathrm{PhD}$ in Economic Sciences, Associate Professor, Moscow Aviation Institute (National Research University), Moscow, Russia.

${ }^{68}$ Doctor in Economic Sciences, Professor, Moscow Aviation Institute (National Research University), Moscow, Russia.
} 


\section{Introduction}

The integrated development of enterprises in modern conditions has a lot of definitions, it includes the stability or growth of such financial and economic activities, as:

- competitiveness of goods and services;

- innovative updating of the product range, technologies, means of labor, and organizational forms of production activity;

- diversification of production;

- $\quad$ effective financial management;

- flexibility and efficiency of control systems.

Of course, the sustainable development of the enterprise is determined by the internal capabilities of the enterprise to develop and implement targeted development strategies (Akimova, 2018). However, the general strategy for the development of industry also affects the activities of a real enterprise. The general direction of scientific, technical, and technological progress in the industry is forcing enterprises with varying degrees of activity to become involved in the process of large-scale modernization of their activities and the achievement of qualitatively new results (Arsenieva et al, 2019c).

This process is also motivated by the opportunity to participate in promising industry projects that are aimed at the development and implementation of unique models of equipment that meet the best world standards. These projects allow enterprises to find sustainability of the economic development for a certain future (Dmitriev \& Novikov, 2020).

\section{Literature Review}

Modern research often uses the concepts of economic sustainability of the enterprise and the sustainability of the economic development (Dreving, 2018). Despite a certain similarity, these concepts are very different. While economic sustainability is mainly concentrated on the results of operations and the margin of the enterprise's efficiency for the future, development sustainability is based on an integrated approach to the problem of enterprise development from the perspective of managing economic potential, production efficiency, and balancing economic growth (Arsenieva et al., 2019a).

Currently, there is a wide variety of assessment methods of economic sustainability of the enterprises and of sustainability of the development (despite their common basis). A variety of methods is associated primarily with the definition of sets of indicators characterizing these components of economic development. Since the economic activity of the enterprise is characterized by relevant indicators, the stability of the economic activity of the enterprise should be considered as the stability of the direction of change in the values of such indicators. The actual dynamics of economic indicators should correspond to the current strategy, so there is a competent compilation and implementation of the strategy. The dynamics of economic indicators are numerically determined by their growth rate (Putyatina et al., 2017).

Types of indicators can be distinguished by considering the existence of an enterprise from three sides: "how many resources an enterprise has", "what an enterprise gets as a result of using resources", "how efficiently an enterprise uses resources". These positions express three main approaches to assessing the economic sustainability of the enterprise: resource-based, efficient, and approach in terms of resource use efficiency (Putyatina et al., 2017).

It is advisable to evaluate approaches to assessing the sustainability of the economic development of the enterprise: in terms of the growth of resources used, from the point of view of increasing the efficiency of the enterprise, of increasing the efficiency or of the use of resources, and from the balanced development of the enterprise (Demin el al., 2016).

\section{Materials and Methods}

It seems appropriate to use an integrated approach to assessing the sustainability of the economic development of the enterprise using the main areas presented in Figure 1. 


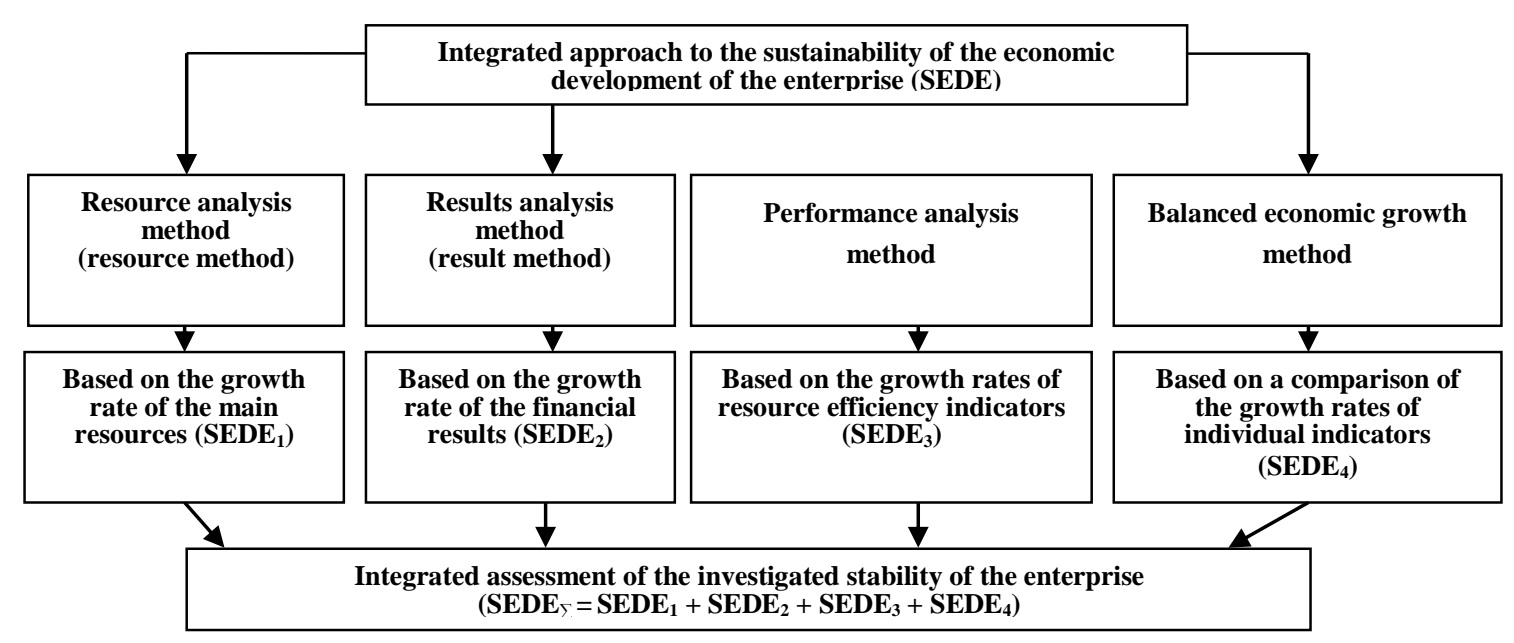

Figure 1. Main areas of research used in a comprehensive sustainability assessment of the economic development of the enterprise (SEDE)

The first (resource) approach is based on an analysis of the dynamics of enterprise resources, i.e. when using it, the rates of their growth (fixed and working capital, headcount, equity, etc.) are calculated. It is not difficult to implement, but does not provide an answer to the question of the effectiveness of the use of resources, taking into account their growth (Novikov \& Gavrilova, 2019).

Using the result approach to assessing the SEDE involves the use of real financial results of the enterprise in the form of revenue and profit, but it does not give the only answer if they are potentially maximum.

When implementing the third approach with resource efficiency (economic potential of the enterprise), the growth rate of resource efficiency indicators are also used.

The fourth approach determines how proportionally the resources of the enterprise change over time in relation to the performance of the enterprise. It is based on a comparison of the growth rates of individual indicators (Popov et al., 2016).

The following approaches used have positive aspects in terms of ease of use, but also there are additional questions about the growth factors of certain indicators.

The distribution of SEDE by levels is given in Table 1.

Table 1.

Levels of economic sustainability of enterprises and their features.

\begin{tabular}{lll}
\hline oo & $\begin{array}{l}\text { Sustainability } \\
\text { level }\end{array}$ & Features \\
\hline \multirow{3}{*}{ High } & $\begin{array}{l}\text { Used resources of the enterprise have a rather high growth trend with an } \\
\text { increase in the enterprise's revenue and profit (more than the industry } \\
\text { average). About } 80 \% \text { of products have a high level of competitiveness. The } \\
\text { enterprise has the financial resources to implement a large-scale innovation } \\
\text { policy with a normal level of financial stability. Balanced development is } \\
\text { ensured fully. } \\
\text { Economic potential of the enterprise based on changes in economic resources } \\
\text { can be defined as relatively stable with a slight growth trend. The increase in } \\
\text { the effectiveness of its use is significant, which means the predominance of } \\
\text { intensive development factors. Competitiveness of products is quite high, but } \\
\text { relatively stable without significant progress over time. Implemented } \\
\text { innovative projects are limited. Financial stability is normal. Balanced } \\
\text { development depends on a lot of indicators. }\end{array}$ \\
& Normal &
\end{tabular}


The enterprise's resources are gradually decreasing at the same time as the results of economic activity are decreasing. Efficiency of resource use has an unstable tendency of small growth and decrease in certain types. Innovative strategy has only a few areas of development. Competitiveness of products in various assortment positions has fluctuations around the lower border of competitiveness. Financial situation is estimated as close to unstable. Balance exists only for certain indicators.

Resources have a downward trend while reducing the enterprise's revenue and profits. Their effectiveness and use also has a decreasing trend.

$4 \quad$ Unstable Competitiveness of enterprise products is gradually decreasing due to its obsolescence. Projects for innovative development of the enterprise are not implemented. Unstable financial condition is observed. More progressive analog products are appearing on the market.

Methodologically, when assessing the growth rates of various indicators by levels of sustainability, it is necessary to take into account industry average values of these indicators or indicators achieved by industry leaders considering the time factor and industry development goals (Zheltenkov et al. 2017).

During the integrated approach to the SEDE, the method of expert assessments is applied, which is implemented first in all areas shown in Figure 1 , and then for the enterprise as a whole with a comprehensive assessment $\left(\mathrm{SEDE}_{\Sigma}\right)$.

The method for the calculations is carried out in as follows:

1. Rationale for the method of comprehensive assessment of the level of $\operatorname{SEDE}\left(\mathrm{SEDE}_{\Sigma}\right)$. In this case, the methods shown in Figure 1 are used.

2. Each direction of calculation has its own system of indicators shown in Table 3, 5, 6, 7.

3. All indicators in accordance with their real values are evaluated by levels: high; normal; low; unstable (Table 2). The basis for comparing indicators is their industry average values or enterprises of the industry leader.

4. Comprehensive assessment of SEDE $\left(\mathrm{SEDE}_{\Sigma}\right)$ is determined in this case by two methods, i.e. simple summation of points for each component:

$\mathrm{SEDE}_{\Sigma}=\mathrm{SEDE}_{1}+\mathrm{SEDE}_{2}+\mathrm{SEDE}_{3}+\mathrm{SEDE}_{4}$. i.e., (1)

$\operatorname{SEDE}_{\Sigma}=\sum_{\mathrm{i}=1}^{4} \mathrm{P}_{\mathrm{i}}$,

where $\sum_{i=1}^{4} P$ is the amount of points that each of the components of sustainability $P_{i}$ of economic development has.

When using the second approach based on the weighting coefficients of significance of each type of stability as part of a comprehensive assessment of $\mathrm{SEDE}_{\Sigma}$, the calculation formula is the following:

$S E D E_{\Sigma}=\sum_{i=1}^{4} P_{i} \times S E D E_{i}$,

If the weighting factors are reasonably distributed between different areas of economic development, the formula will be as follows:

$\mathrm{SEDE}_{\Sigma}=0.25 \mathrm{SEDE}_{1}+0.35 \mathrm{SEDE}_{2}+0.30 \mathrm{SEDE}_{3}+0$ . $\mathrm{SEDE}_{4}$. (4)

Based on the total score, taking into account the criteria Table 2, the enterprise is assigned a certain level of sustainability.

Table 2.

System of point estimates (criteria) for a comprehensive assessment of the level of sustainability of economic development $\left(S E D E_{\Sigma}\right)$ of the enterprise.

\begin{tabular}{lcclll}
\hline $\begin{array}{l}\text { Type of } \\
\text { sustainability }\end{array}$ & \multicolumn{2}{c}{ Stability levels (points) } & low & unstable & Significance weight \\
\cline { 2 - 4 } & $\begin{array}{l}\text { high } \\
\text { coefficient }\left(\mathbf{W}_{\mathbf{i}}\right)\end{array}$ & normal & low & & \\
$\mathrm{SEDE}_{1}$ (points) & $>60$ & $\geq 40 \div \leq 60$ & $\geq 20 \div \leq 40$ & $<20$ & \\
$\mathrm{SEDE}_{2}$ (points) & $>60$ & $\geq 40 \div \leq 60$ & $\geq 20 \div \leq 40$ & $<20$ & \\
$\mathrm{SEDE}_{3}$ (points) & $>60$ & $\geq 40 \div \leq 60$ & $\geq 20 \div \leq 40$ & $<20$ & \\
$\mathrm{SEDE}_{4}$ (points) & $>60$ & $\geq 40 \div \leq 60$ & $\geq 20 \div \leq 40$ & $<20$ & \\
\hline
\end{tabular}




\begin{tabular}{rrllll}
$\mathbf{S E D E}_{\boldsymbol{\Sigma}}$ (points) & $>240$ & $\geq 160 \div \leq 240$ & $\geq 80 \div \leq 160$ & $<80$ & \\
\multicolumn{2}{|c|}{ method } & & & & \\
$\mathrm{SEDE}_{1}$ (points) & $>12$ & $\geq 9 \div \leq 12$ & $\geq 6 \div \leq 9$ & $<6$ & 0.25 \\
$\mathrm{SEDE}_{2}$ (points) $>12$ & $\geq 9 \div \leq 12$ & $\geq 6 \div \leq 9$ & $<6$ & 0.35 \\
$\mathrm{SEDE}_{3}$ (points) $>12$ & $\geq 9 \div \leq 12$ & $\geq 6 \div \leq 9$ & $<6$ & 0.30 \\
$\mathrm{SEDE}_{4}$ (points) $>12$ & $\geq 9 \div \leq 12$ & $\geq 6 \div \leq 9$ & $<6$ & 0,1 \\
$\mathrm{SEDE}_{\boldsymbol{\Sigma}}$ (points) & $>48$ & $\geq 36 \div \leq 48$ & $\geq 24 \div \leq 36$ & $<24$ & 1 \\
\hline
\end{tabular}

For example, using the first method for $\mathrm{SEDE}_{1}$ the interpretation of the calculated values is as follows: if the score for $\mathrm{SEDE}_{1}>60$, this direction of the studied stability is assigned a high level; at $40 \leq \mathrm{SEDE}_{1} \leq 60$ the normal level is assigned; at $20 \leq \mathrm{SEDE}_{1} \leq 40$ the low level is assigned; at $\mathrm{SEDE}_{1}<20$ the unstable level is assigned.

\section{Determining the SEDE on the Basis of the Above Assessment Methods}

To consider the activities of the enterprise in terms of changes in the volume of its resources, appropriate types of resources should be allocated: material (fixed and working capital), labor, and financial (equity). The growth of the enterprise's used resources is very important, but it is not the only condition for its development. For the studying method it is advisable to use the following indicators (Table 3):

Growth rate of the fixed capital $\left(G R_{C_{f i x}}\right)$, which is determined by Putyatina and Rodinov (2006):

$G R_{C_{f i x}}=\frac{C_{f i x}^{\text {plan }}}{C_{f i x}^{\text {base }}}$,

where $C_{\text {fix }}^{\text {plan }}, C_{\text {fix }}^{\text {base }}$ are the costs of the main production capital of the enterprise, respectively, in the planning and base periods (thousand rubles).

The growth rate of this indicator determines the technical and technological activity of the enterprise, possibility of modernizing the material and technical base of production, and innovative technologies using new machines and equipment. An increase in the growth rate of fixed capital in the general case contributes to an increase in the level of its SEDE.

Growth rate of the working capital $\left(G R_{C_{\text {work }}}\right)$, which is determined by Putyatina and Rodinov (2006):

$G R_{C_{\text {work }}}=\frac{C_{\text {work }}^{\text {plan }}}{C_{\text {work }}^{\text {base }}}$ where $C_{\text {work }}^{\text {plan }}, C_{\text {work }}^{\text {plan }}$ are the values of the working capital of the enterprise, respectively, in the planning and base periods (thousand rubles).

In the general case, the growth of working capital makes it possible to expand production, however, this growth should correspond to the growth in output in physical and value terms. If the growth of working capital significantly exceeds the results of economic activity, it can be considered irrational in terms of enterprise costs.

Growth rate of the number of industrial production personnel ( $\left.G R_{N_{I P P}}\right)$, which is determined by Putyatina and Rodinov (2006):

$G R_{N_{I P P}}=\frac{N_{I P P}^{\text {plan }}}{N_{I P P}^{\text {base }}}$

where $N_{I P P}^{\text {plan }}, N_{I P P}^{\text {base }}$ are the numbers of industrial and production personnel (IPP) of the enterprise, respectively, in the planned and base periods (people).

Since the personnel of enterprises plays a crucial role in solving the strategic tasks of enterprise development, the growth of its number implies the expansion of production in the future and at the same time increases its economic potential.

Growth rate of the enterprise's own capital $\left(G R_{C_{o w n}}\right)$, which is determined by Zheltenkov et al. (2012):

$G R_{C_{o w n}}=\frac{c_{o w n}^{\text {plan }}}{C_{\text {own }}^{\text {plan }}}$

where $C_{\text {own }}^{\text {plan }}, C_{\text {own }}^{\text {plan }}$ are the amounts of equity capital of the enterprise, respectively, in the planning and base periods (thousand rubles).

An increase in the enterprise's own funds reduces the level of its financial dependence and increases the level of self-financing of development.

Depreciation of fixed assets $\left(D_{f i x}\right)$, which is determined by Putyatina and Rodinov (2006): 
$D_{f i x}=\frac{D_{f u n d \Sigma}}{C_{f i x}^{\text {ini }}}$,

where $D_{\text {fund }}$ is the total depreciation fund of the enterprise (rubles);

$C_{\text {fix }}^{i n i}$ is the initial cost of the fixed capital of the enterprise on the relevant date (rubles).
The physical condition of fixed assets of the enterprise to a large extent determines the quality of operations and products in general. In the process of activity, the enterprise, in accordance with the plan for equipment modernization and its renovation, should regularly monitor its condition and timely replace it with new modern types of labor equipment (Radievsky, 2018).

Table 3.

Key indicators determined the level of enterprise sustainability based on the resource approach (SEDE $\left.E_{1}\right)$

\begin{tabular}{|c|c|c|c|c|c|c|c|c|c|}
\hline \multirow[b]{2}{*}{ № } & \multirow{3}{*}{$\begin{array}{l}\text { Indicator name } \\
\text { Growth rate of the } \\
\text { fixed capital }\end{array}$} & \multirow{3}{*}{$\begin{array}{l}\text { Symbol } \\
\qquad G R_{C_{f i x}}\end{array}$} & \multirow[b]{2}{*}{ Unit of measurement } & \multicolumn{2}{|c|}{ Sustainability score } & \multirow[b]{2}{*}{ low } & \multirow[b]{2}{*}{ unstable } & \multirow{2}{*}{$\begin{array}{l}\text { Significance } \\
\text { weight } \\
\text { coefficient } \\
\text { (Wi) }\end{array}$} & \multirow{2}{*}{$\begin{array}{l}\text { Average } \\
\text { value for the } \\
\text { industry }\end{array}$} \\
\hline & & & & high & normal & & & & \\
\hline 1 & & & non-dimensional & $>G R_{C_{f i x}^{a v}}$ & $\cong G R_{C_{f i x}^{a v}}$ & $<G R_{C_{f i x}^{a y}}$ & $\ll G R_{C_{f i x}^{a v}}$ & 0.30 & $G R_{C_{f i x}^{a p}}$ \\
\hline 2 & $\begin{array}{l}\text { Growth rate of the } \\
\text { working capital }\end{array}$ & $\boldsymbol{G} \boldsymbol{R}_{C_{\text {work }}}$ & non-dimensional & $>G R_{C_{\text {Work }}^{a v}}$ & $\cong G R_{C_{\text {work }}^{a v}}$ & $<G R_{C_{w o r k}^{a v}}$ & $\ll G R_{C_{\text {work }}^{a v}}$ & 0.20 & $G R_{C_{\text {work }}^{a v}}$ \\
\hline 3 & $\begin{array}{l}\text { Growth rate of the } \\
\text { number of } \\
\text { industrial } \\
\text { production } \\
\text { personnel }\end{array}$ & $G R_{N_{I P P}}$ & non-dimensional & $>G R_{N_{I P P}^{a p}}$ & $\cong G R_{N_{I P P}^{a p}}^{a p}$ & $<G R_{N_{I P P}^{a p}}$ & $\ll G R_{N_{I P P}^{a v}}^{a v}$ & 0.15 & $G R_{N_{I P P}^{a v}}^{a v}$ \\
\hline 4 & $\begin{array}{l}\text { Growth rate of the } \\
\text { enterprise's own } \\
\text { capital }\end{array}$ & $\boldsymbol{G} \boldsymbol{R}_{C_{\text {own }}}$ & non-dimensional & $>1.15$ & $1.15 \div 1.10$ & $<1.1$ & $\leq 1.0$ & 0.15 & $G R_{C_{o w n}^{a v}}$ \\
\hline 5 & $\begin{array}{l}\text { Depreciation of } \\
\text { fixed assets }\end{array}$ & $D_{f i x}$ & non-dimensional & $<0.6$ & $0.6-0.7$ & $>0.7$ & $>>0.7$ & 0.2 & $D_{f i x}^{a v}$ \\
\hline & Total: & & & & & & & 1.0 & \\
\hline
\end{tabular}

$\mathrm{SEDE}_{2}$ based on the resultant approach is advisable to conduct on the basis of a system of the following indicators (Table 4):

Enterprise revenue growth rate $\left(G R_{Q_{e n t}}\right)$, which is determined by:

$G R_{Q_{\text {ent }}}=\frac{Q_{\text {ent }}^{\text {plan }}}{Q_{\text {ent }}^{\text {base }}}$,

where $Q_{\text {ent }}^{\text {plan }}, Q_{\text {ent }}^{\text {base }}$ are the enterprise's revenues, respectively, in the planned and base periods (thousand rubles).

The enterprise's revenue shows the number of products sold by the enterprise at current market prices. If the enterprise's revenue grows over time, the financial results of the enterprise increase, production volumes increase and show the enterprise the potential for future growth. The exception is the situation when revenue growth is mainly due to rising product prices. In this case, the economic growth of the enterprise must be recognized as passive and possibly accidentally formed in connection with a change in market conditions.
Growth rate of balance profit $\left(G R_{P R_{b a l}}\right)$, which is determined by:

$G R_{P R_{b a l}}=\frac{P R_{\text {bal }}^{\text {plan }}}{P R_{\text {bal }}^{\text {base }}}$,

where $P R_{\text {bal }}^{\text {plan }}, P R_{\text {bal }}^{\text {base }}$ are the balance sheet profits of the enterprise, respectively, in the planned and base periods (thousand rubles).

The balance sheet profit of the enterprise is a part of gross revenue, which is obtained after deducting all expenses of the enterprise for all types of activity for the considered period of time. This indicator characterizes the economic profitability of all industrial and commercial activities of the enterprise for the considered period of time (Arsenieva et al., 2019b):

$P R_{\text {bal }}=P R_{\text {prod }}+P R_{\text {serv }}+P R_{\text {fix }}+P R_{N O}$,

where $P R_{\text {prod }}$ is the profit from the sale of marketable products (rubles);

$P R_{\text {serv }}$ is the profit from the sale of additional services provided by the enterprise (rubles);

$P R_{f i x}$ is the profit from sale of fixed assets (rubles); 
$P R_{N O}$ is the profit from non-operating operations (rubles).

The increase in the growth rate of the balance sheet profit of the enterprise indicates an increase in the efficiency of production and commercial activities of the enterprise and requires a structural analysis of its actual growth.

Growth rate of the average wage $\left(G R_{\text {wage }_{a v}}\right)$, which is determined by (Arsenieva et al., 2019c):

$G R_{\text {wage }_{a v}}=\frac{\text { wage }_{a v}^{\text {plan }}}{\text { wage }_{a v}^{\text {base }}}$

where wage $_{a v}^{\text {plan }}$, wage av $_{\text {base }}$ are the sizes of the average wage of the IPP of the enterprise, respectively, in the planned and base periods (rubles).

Table 4.

Calculation of coefficient elements of innovative activity of the Enterprise.

\begin{tabular}{|c|c|c|}
\hline Indicator name & Designation and formula & $\begin{array}{l}\text { Valid } \\
\text { values }\end{array}$ \\
\hline $\begin{array}{l}\text { Coefficient of renewal of fixed } \\
\text { assets. This indicator determines the } \\
\text { level of renewal of fixed assets for the } \\
\text { future operation of the enterprise, } \\
\text { while reducing the total depreciation } \\
\text { of fixed assets. }\end{array}$ & $\begin{array}{l}C_{r e n}=\frac{c_{f i x}^{i n}}{C_{f i x}^{a v}} \text {, where } \\
C_{f i x}^{i n} \text { is the cost of input, new fixed assets (thousand rubles). } \\
C_{f i x}^{a v} \text { is the average annual value of fixed assets of the enterprise } \\
\text { (thousand rubles). }\end{array}$ & $\mathbf{0}-\mathbf{1}$ \\
\hline $\begin{array}{l}\text { Share of new products in the total } \\
\text { revenue of the enterprise. This } \\
\text { indicator determines the innovative } \\
\text { activity of the enterprise from the } \\
\text { position of developing new promising } \\
\text { products. }\end{array}$ & $\begin{array}{l}S_{\text {new prod. }}=\frac{Q_{\text {sale }}^{\text {new }}}{Q_{\text {sale }}^{\text {tatal }}} \text { where } \\
Q_{\text {sale }}^{\text {new }} \text { is the revenue of the enterprise from the sale of new } \\
\text { products (thousand rubles); } \\
Q_{\text {salal }}^{\text {total }} \text { is the total revenue of the enterprise from the sale of all } \\
\text { products (thousand rubles). }\end{array}$ & $\mathbf{0}-\mathbf{1}$ \\
\hline $\begin{array}{l}\text { Share of the use of new materials. } \\
\text { This indicator shows the share of } \\
\text { enterprise costs for new and more } \\
\text { promising types of materials in } \\
\text { their total amount. }\end{array}$ & $\begin{array}{l}S_{\text {new mat. }}=\frac{C o_{\text {mat }}^{\text {new }}}{C o_{\text {mat }}^{\text {tot }}} \\
C o_{\text {mat }}^{\text {new }} \text { is the costs of new materials used in the manufacture of } \\
\text { products (thousand rubles); } \\
C o_{\text {mat }}^{\text {total }} \text { is the total costs of the enterprise for materials } \\
\text { (thousand rubles) }\end{array}$ & 0 - 1 \\
\hline
\end{tabular}

Coefficient of investment activity $\left(C_{i n v}\right)$ can be calculated as follows:

$C_{i n v}=\frac{I n P r_{\text {constr }}+P R_{i n v}+L T_{f i n}}{T V_{n c}}$,

where $I n P r_{\text {constr }}$ is the construction in progress (thousand rubles);

$P R_{\text {inv }}$ are the profitable investments in material values (thousand rubles);

$L T_{\text {fin }}$ are the long-term financial investments (thousand rubles);
Improving the financial results of the enterprise should directly affect the level of social protection of workers, which is realized on the basis of increasing the average salary of personnel.

Coefficient of innovation activity ( $C_{i n n}$ ) is determined by:

$C_{i n n}=$ $\sqrt[3]{\left(1+C_{\text {ren }}\right) \times\left(1+S_{\text {new prod. }}\right) \times\left(1+S_{\text {new mat }}\right)}$ 1 , (14)

where the main components are given in Table 4.

The coefficient of innovation activity is a comprehensive indicator, in this case, taking into account the introduction of three types of innovation: fixed assets, products, and materials. The growth trend of the indicator determines its development along the innovative path.
$T V_{n c}$ is the total value of non-current assets of the enterprise (thousand rubles).

This indicator characterizes investment activity and determines the amount of funds aimed at the modification and implementation of promising innovative projects. The indicators for assessing the level of enterprise sustainability based on the result approach $\left(\mathrm{SEDE}_{2}\right)$ are given in Table 5. 
Table 5.

Main indicators determined the level of the enterprise's stability with the results of its activities (SEDE $\left.E_{2}\right)$

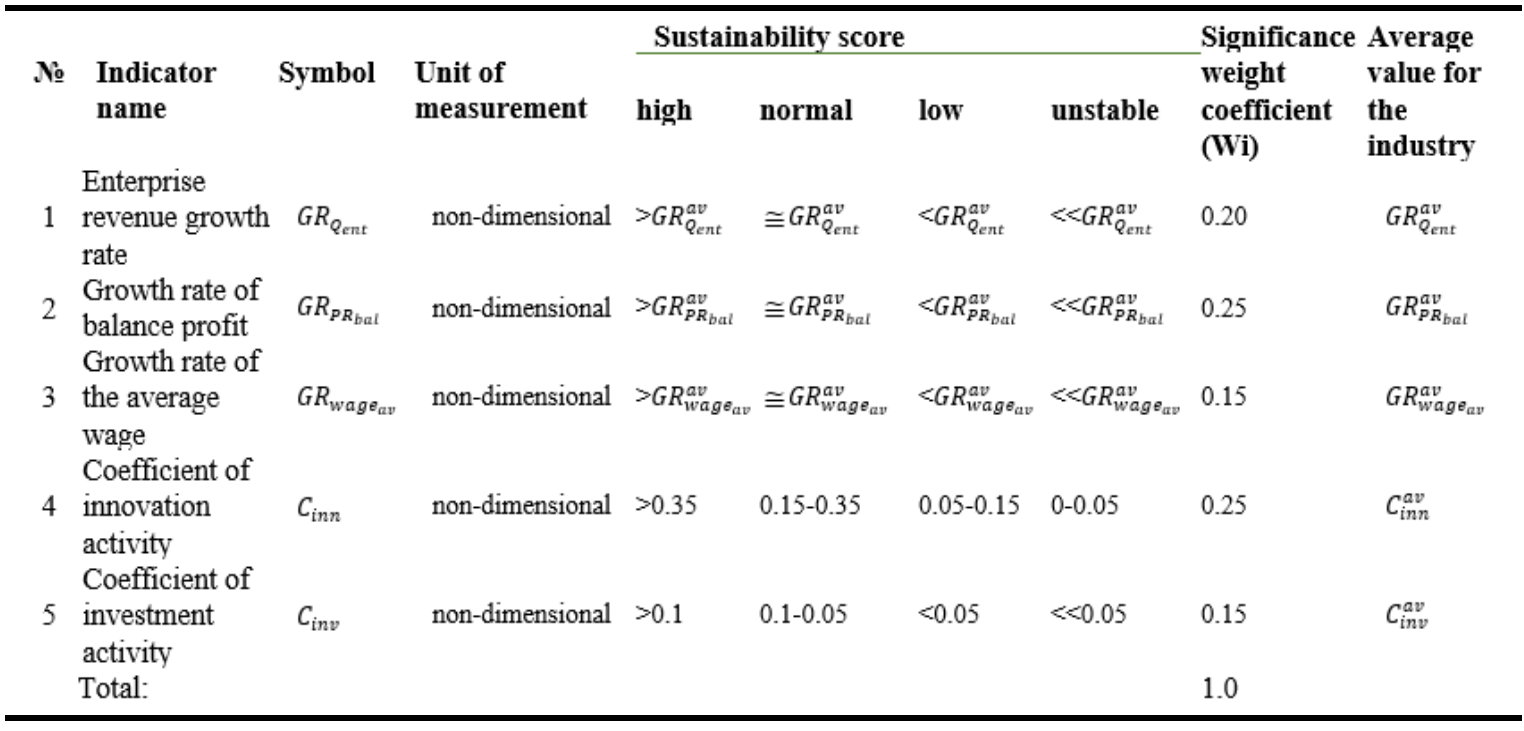

SEDE based on resource efficiency indicators $\left(\mathrm{SEDE}_{2}\right)$ is advisable to carry out on the basis of a system of the following indicators (Table 6) (Putyatina and Rodinov 2006):

Growth rate of production $\left(G R_{\text {prod }_{1 I P P}}\right)$ per 1 average employee of the IPP of the enterprise is determined by:

$G R_{\text {Prod }_{1 i p p}}=\frac{\operatorname{Prod}_{1 I P P}^{\text {plan }},}{\operatorname{Prod}_{1 I P P}^{\text {base }}}$

where $\operatorname{Prod}_{1 I P P}^{\text {plan }}$, Prod $\operatorname{lIIPP}_{\text {base }}$ are the products per 1 average employee of the IPP of the enterprise, respectively, in the planned and base periods (thousand rubles/person).

Production or labor productivity determines not only the efficiency of use of labor resources, but also the overall performance of the enterprise, and calculated as follows:

$\operatorname{Prod}_{1 i p p}=\frac{Q_{\mathrm{p}}}{N_{I P P}^{a v}}$

where $Q_{\text {sold }}$ is the annual volume (revenue) of products sold by the enterprise at current market prices (thousand rubles);

$N_{I P P}^{a v}$ is the the average number of industrial production personnel of the enterprise (people).

The higher the growth rate of labor productivity in an enterprise, the more efficiently its labor and aggregate economic potential is used and, correspondingly, the higher is the level of sustainability of its economic development (Putyatina and Rodinov 2006).

Growth rate of capital productivity $\left(G R_{C P}\right)$ is determined by:

$G R_{C P}=\frac{C P^{\text {plan }}}{C P^{\text {base }}}$,

where $C P^{\text {plan }}, C P^{\text {base }}$ are the returns on assets of the enterprise, respectively, in the planning and base periods (rubles/rubles).

Capital productivity ( CP ) characterizes the efficiency of using fixed assets of the enterprise or its technical potential. It is calculated:

$C P=\frac{Q_{e n t}}{C_{f i x}^{a v}}($ rubles/ rubles $)$,

where $Q_{\text {ent }}$ is the revenue of the enterprise (thousand rubles);

$C_{f i x}^{a v}$ is the average annual value of the fixed capital of the enterprise (thousand rubles), which is calculated:

$C_{f i x}^{a v}=\frac{\left(C_{f i x}^{b e g}+C_{f i x}^{e n d}\right)}{2}$

where $C_{f i x}^{\text {beg }}, C_{f i x}^{e n d}$ are the total amounts of fixed assets of the enterprise, respectively, at the beginning and end of the year (thousand rubles). 
The higher this indicator, the higher the efficiency of use of fixed assets of the enterprise and the higher its stability.

Growth rate of the working capital turnover coefficient $\left(G R_{C_{\text {work }}^{\text {turn }}}\right)$ is determined by:

$G R_{C_{\text {work }}^{\text {turn }}}=\frac{C_{\text {work }}^{\text {turn plan }}}{C_{\text {work }}^{\text {turn base }}}$

where $C_{\text {work }}^{\text {turn plan }}, C_{\text {work }}^{\text {turn base }}$ are the turnover ratios of working capital of the enterprise, respectively, in the planning and base periods (rubles/rubles).

Turnover coefficient of working capital $\left(C_{\text {work }}^{\text {turn }}\right)$ characterizes the number of rubles of products sold per 1 ruble of the average annual amount of working capital of the enterprise (Atkisson, 2015):

$C_{\text {work }}^{\text {turn }}=\frac{Q_{\text {sold }}}{C_{\text {work }}^{\text {av }}}$,

where $Q_{\text {sold }}$ is the annual volume (revenue) of products sold by the enterprise at current market prices (thousand rubles);

$C_{\text {work }}^{a v}$ is the average annual value of the total amount of working capital of the enterprise (thousand rubles), which is calculated:

$C_{\text {work }}^{\text {av }}=\frac{\left(C_{\text {work }}^{\text {beg }}+C_{\text {work }}^{\text {end }}\right)}{2}$,

where $C_{\text {work }}^{\text {beg }}, C_{\text {work }}^{\text {end }}$ are the total amounts of working capital of the enterprise, respectively, at the beginning and end of the year (rubles).

The dynamics of the increase in the indicator $C_{\text {work }}^{\text {turn }}$ over time indicates an increase in the efficiency of the enterprise using working capital, which not only reduces the funds in the enterprise's turnover, but also provides additional profit by reducing the used credit resources (Komarova et al., 2019).

Return on sales $\left(R_{\text {sale }}\right)$ characterizes the level of efficiency of industrial and commercial activities of the enterprise and is calculated as follows (Putyatina \& Rodinov, 2006):

$R_{\text {sale }}=\frac{P R_{\text {bal }}}{Q_{\text {ent }}} \times 100 \%$,

If the structure of retained earnings has several directions for its receipt, for greater accuracy of this indicator, it is necessary to calculate an updated indicator of profitability of turnover $\left(R_{\text {sale }}^{*}\right)$ based on profit from main commodity production $\left(P R_{\text {prod }}\right)$, i.e.:

$R_{\text {sale }}^{*}=\frac{P R_{\text {prod }}}{Q_{\text {ent }}} \times 100 \%$,

The higher the growth rate of profitability of an enterprise's turnover, the more actively it gains an increased level of stability in a competitive environment.

Coverage coefficient $\left(C_{\text {cov }}\right)$, (current liquidity coefficient) is determined by:

$C_{c o v}=\frac{\mathrm{A}_{\mathrm{o}}}{S T}$,

where $S T$ are the short-term liabilities, which are calculated as the sum of loans and credits, payables, debts to participants (founders) for the payment of income, and other short-term liabilities (thousand rubles);

$A_{c}$ is the amount of current assets of the enterprise.

The standard value of the coverage factor should be $C_{\text {cov }} \geq 2$.

For machine-building enterprises, the necessary value is difficult to obtain, so analysts believe that if the figure is $>1.5$, this is quite acceptable.

It should be noted that in European practice this standard is differentiated by industry and by subindustry. This allows to more correctly differentiating the solvency of enterprises based on their specialization (Novikov, 2018). 
Table 6.

Key indicators used by the resource efficiency method ( $\left.S E D E_{3}\right)$

\begin{tabular}{|c|c|c|c|c|c|c|c|c|c|}
\hline \multirow[t]{2}{*}{ № } & \multirow{2}{*}{ Indicator Name } & \multirow{2}{*}{ Symbol } & \multirow{2}{*}{$\begin{array}{l}\text { Unit of } \\
\text { measurement }\end{array}$} & \multicolumn{4}{|c|}{ Sustainability score } & \multirow{2}{*}{$\begin{array}{l}\text { Significance } \\
\text { weight } \\
\text { coefficient } \\
\text { (Wi) }\end{array}$} & \multirow{2}{*}{$\begin{array}{l}\text { Average } \\
\text { value for } \\
\text { the } \\
\text { industry }\end{array}$} \\
\hline & & & & high & normal & low & unstable & & \\
\hline 1 & $\begin{array}{l}\text { Growth rate of } \\
\text { production } \\
\text { (per } 1 \text { IPP) }\end{array}$ & $G R_{\text {prod }_{1 I P P}}$ & non-dimensional & $>G R_{\text {Prod }_{1 I P F}}^{a v}$ & $\begin{array}{l}= \\
P G R_{P_{r o d}}^{a v}{ }_{1 I P P}\end{array}$ & $<G R_{P_{r o d_{1 I P P}}^{a v}}$ & $\begin{array}{l}\ll \\
{ }^{G} R_{\text {Prod }_{1 I P P}}^{a v}\end{array}$ & 0.30 & $G R_{\text {Prod }_{1 I P P}}^{a v}$ \\
\hline 2 & $\begin{array}{l}\text { capital } \\
\text { productivity } \\
\text { Growth rate of the }\end{array}$ & $G R_{C P}$ & non-dimensional & $>G R_{C P}^{a v}$ & $=G R_{C P}^{a v}$ & $<G R_{C P}^{a v}$ & $\ll G R_{C P}^{a v}$ & 0.10 & $G R_{C P}^{a v}$ \\
\hline 3 & $\begin{array}{l}\text { working capital } \\
\text { turnover } \\
\text { coefficient }\end{array}$ & $G R_{C_{\text {work }}^{\text {turn }}}$ & non-dimensional & $>G R_{c_{w o r k}^{\text {turn }}}^{\text {tur }}$ & $=G R_{c_{\text {work }}^{\text {turn }}}^{a v}$ & $<G R_{c_{\text {work }}^{\text {turn }}}^{a v}$ & $\ll G R_{c_{\text {work }}^{\text {turn }}}^{a v}$ & 0.2 & $G R_{c_{\text {work }}^{\text {turn }}}^{\text {av }}$ \\
\hline 4 & Return on sales & $R_{\text {sale }}$ & non-dimensional & $>20 \%$ & $20 \% \div 10 \%$ & $<10 \%$ & $\leq 0$ & 0.15 & $R_{\text {sale }}^{a v}$ \\
\hline 5 & $\begin{array}{l}\text { Coverage } \\
\text { coefficient }\end{array}$ & $C_{c o v}$ & non-dimensional & $>1.5$ & $1 \div 1.5$ & $<1$ & $\ll 1$ & 0.25 & - \\
\hline \multicolumn{2}{|c|}{ Total: } & & & & & & & 1.0 & \\
\hline
\end{tabular}

Using Analytical Approach to the Assessment of SEDE Based on Balance (SEDE 4 )

Using this approach, the growth rates of certain indicators are compared. Relative balance is performed if:

1. balance sheet profit of an enterprise grows faster than its revenue for a similar period of time, since this is determined by the "golden rule of the economy". The use of this inequality allows assessing the ability of the enterprise to manage costs effectively, which have certain reserves of reduction and rationally use the effects of production and financial leverage;

2. enterprise's revenue increases faster than the growth of working capital, which indicates the rational use of working capital, the management of which demonstrates a high level of control over all elements of working capital and the presence of certain savings in production and distribution costs;
3. output per employee of the IPP is growing faster than the average wage which ensures the formation of an increase in selfinvestment funds for the development of production in general and the solution of social problems of the enterprise team in particular;

4. output per employee of the IPP is growing faster than the number of the IPP. This means that with an increase in production volumes, the enterprise uses modern means of labor and new technologies that reduce the complexity of production, increase the productivity of managerial labor and allow having additional economic growth and competitive advantages in the industry market;

5. average wage of employees is growing faster than inflation. This is possible when increasing the efficiency of a sustainable enterprise is able to fully provide social protection to its employees.

Table 7.

Using an analytical approach to balanced SEDE assessment (SEDE 4 )

\begin{tabular}{|c|c|c|c|c|c|c|}
\hline \multirow[b]{2}{*}{ № } & \multirow[b]{2}{*}{ Main relationships } & \multicolumn{4}{|c|}{ Sustainability score } & \multirow[b]{2}{*}{ Weight coefficient (Wi) } \\
\hline & & high & normal & $\begin{array}{l}\text { lo } \\
\text { w }\end{array}$ & unstable & \\
\hline 1 & $G R_{P R_{b a l}}>G R_{Q_{e n t}}$ & $>10 \%$ & $>5 \%$ & $\cong$ & $<$ & 0.3 \\
\hline 2 & $G R_{Q_{\text {ent }}}>G R_{C_{\text {work }}}$ & $>10 \%$ & $>5 \%$ & $\cong$ & $<$ & 0.15 \\
\hline 3 & $G_{\text {Prod }_{1 I P P}}>G R_{\text {wage }_{a v}}$ & $>10 \%$ & $>5 \%$ & $\cong$ & $<$ & 0.25 \\
\hline 4 & $G R_{\operatorname{Prod}_{1 I P P}}>G R_{N_{I P P}}$ & $>10 \%$ & $>5 \%$ & $\cong$ & $<$ & 0.1 \\
\hline 5 & $G R_{\text {wage }_{\text {av }}}>G R_{\text {inflation }}$ & $>10 \%$ & $>5 \%$ & $\cong$ & $<$ & 0.2 \\
\hline Total: & & & & & & 1.0 \\
\hline
\end{tabular}




\section{Results and Discussion}

Based on calculations of a complex indicator of the sustainability level of development using two methods, based on (4), the following results are obtained:

1. according to the first method: $\operatorname{SEDE}_{\Sigma}=$ $\mathrm{SEDE}_{1}+\mathrm{SEDE}_{2}+\mathrm{SEDE}_{3}+\mathrm{SEDE}_{4}=45+$ $60+75+65=245$, which corresponds to a high level of sustainability of enterprise development;

2. according to the second method: $\mathrm{SEDE}_{\Sigma}$ $=0.25 \mathrm{SEDE}_{1}+0.35 \mathrm{SEDE}_{2}+0.30 \mathrm{SEDE}_{3}+$ $0.1 \mathrm{SEDE}_{4}=45 * 0.25+60 * 0.35+75 *$ $0.3+65 * 0.1=61.25$, which also corresponds to a high level of sustainability of the enterprise.

Despite the fact that the enterprise has ascertained a normal level of development sustainability based on calculations using resource and result approaches, calculations of enterprise efficiency in the development process and balance showed a high level of sustainability. In an integrated assessment based on the two described methods, an enterprise can recognize a high level of development sustainability over the period under consideration.

In recent years, many research papers on the topic of the sustainability of economic systems have appeared. This is due to the development of competition within the country (industry) and in the global economy. The stability of various lines of activity of enterprises is studied: finance, economics, labor potential, etc. (Poloskov \& Zheltenkov, 2018).

Many researchers identify economic sustainability with the sustainability of economic development of enterprises, although in these concepts there are many things that separate them.

There is the discussion about the structure of areas included in the study of the sustainability of economic development, list of indicators used for their analysis, and limits of change of individual characteristics, reflecting levels of sustainability. Moreover, each study has its own logic and right to exist.

\section{Conclusions}

In modern studies on the theory of stability of economic systems, there are a significant number of its types. The sustainability of enterprises is understood as their ability to carry out business activities relatively stable taking into account constant changes in the external conditions of the economic environment and the development of internal resources.

A number of factors influence on the sustainable development of enterprises: macroeconomic factors that determine the overall development of the economy and industry, industrial, social, environmental, market factors, and internal factors of enterprise development, capable of ensuring sustainable economic growth.

The development of enterprises and companies is an objective necessity for the existence of business entities operating. It provides enterprises with future stability and competitive advantage in the current time period. However, the concept of development in various economic conditions can be interpreted differently, taking into account the characteristics of the period, state priorities, level of progress in science and technology, etc.

The external environment of enterprises can be in a state of large-scale progress in the economy, stability, and in crisis. This stimulates or suppresses the development process to a certain extent, and must be taken into account in studies on the theory of sustainability in general and sustainability of economic development in particular (Zamkovoi et al., 2019).

In any case, the methods and approaches developed in the field of sustainability of economic development of enterprises make a certain scientific contribution to the theory of sustainability.

\section{References}

Akimova, T.A. (2018). Fundamentals of sustainable development economics. Textbook for universities. Moscow: Economics.

Arsenieva, N.V., Lavrova, L.A., Putyatina, L.M., \& Tarasova, N.V. (2019a). An integrated approach to the problem of economic growth of machine-building enterprises in modern conditions. Bulletin of Moscow State Regional University. Series: Economics, 3, 28-38.

Arsenieva, N.V., Putyatina, L.M., \& Barsova, T.N. (2019b). Sustainability of the development of scientific and production organizations in the conditions of innovative development of the Russian economy. Bulletin of Moscow State Regional University. Series: Economics, 2, 37-44.

Arsenieva, N.V., Putyatina, L.M., \& Zheltenkov, A.V. (2019c). Actual problems of 


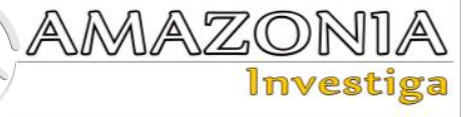

increasing the competitiveness of machinebuilding enterprises in modern conditions. Bulletin of the University, 7, 41-45.

Atkisson, A. (2015). How sustainable development can change the world. Moscow: Binomial. Knowledge lab.

Demin, S.S., Arsenieva, N.V., \& Petrov, D.G. (2016). Issues of managing innovative modernization of domestic high-tech industries. Pumps, Turbines, Systems, 2(19), 3-12.

Dmitriev, O.N., \& Novikov, S.V. (2020). Expanding Research and Development at Russian High-Tech Enterprises: Conceptual Approach. Russian Engineering Research, 40(2), 140-142.

Dreving, S.R. (2018). Cluster concept of sustainable economic development. Moscow: Publishing House of St. Petersburg University.

Komarova, N.V., Zamkovoi, A.A., \& Novikov, S.V. (2019). The Fourth Industrial Revolution and Staff Development Strategy in Manufacturing. Russian Engineering Research, 39(4), 330-333.

Novikov, S.V. (2018). The features of innovative processes in the Russian Federation: Analysis of current practices. Espacios, 39(39), 2.

Novikov, S.V., \& Gavrilova, I.S. (2019). Key indicators of innovation activity of Russian industrial production organizations. Espacios, 16(40).

Poloskov, S.S., \& Zheltenkov, A.V. (2018). High-tech and high-tech enterprises and their positioning in a competitive environment. Bulletin of the Moscow State Regional University. Series: Economics, 2, 155-163.

Popov, R.A., Sekisov, A.N., \& Shipilova, N.A. (2016). The Economics of Innovation in Modern Russia: Practice, Problems and Prospects.
International Journal of Economics and Financial Issues, 6(8S), 184-188.

Putyatina, L.M., \& Rodinov, V.B. (2006). Economics and enterprise finance, textbook. Moscow: Economics and Finance.

Putyatina, L.M., Barsova, T.N., \& Orlova, O.V. (2017). The study of the main aspects of the innovation policy of the enterprise in the domestic industry. Bulletin of the University (State University of Management), 1, 35-38.

Putyatina, L.M., Uglova, L.A., \& Greshnevikova, N.A. (2017). Features of the implementation of the innovation policy of machine-building enterprises in modern conditions. Bulletin of the Moscow State Regional University, 1, 83-87.

Radievsky, M.V. (2018). Organization of production: an innovative strategy for the sustainable development of the enterprise. Textbook. Moscow: INFRA-M.

Zamkovoi, A.A., Komarova, N.V., \& Novikov, S.V. (2019). Rethinking the Education of Aviation Specialists for a New Era. Russian Engineering Research, 39, 268-271.

Zheltenkov, A.V., Zhurakhovskaya, I.M., Semenovich, V.S., Ryabichenko, S.A., Braga, I.V., \& Fimushkin, Y.K. (2012). Fundamentals of management: a training manual. Moscow: Publishing House of Moscow State Regional University.

Zheltenkov, A., Syuzeva, O., Vasilyeva, E., \& Sapozhnikova, E. (2017). Development of investment infrastructure as the factor of the increase in investment attractiveness of the region. Energy Management of Municipal Transportation Facilities and Transport. Khabarovsk: Far Eastern State Transport University. 